\title{
Is There a Lean Future for Global Startups? Stoyan Tanev
}

\author{
"In real life, unlike in Shakespeare, the sweetness" \\ of the rose depends upon the name it bears. \\ Things are not only what they are. They are, in \\ very important respects, what they seem to be. \\ Hubert Humphrey (1911-1978) \\ 38th Vice President of the United States
}

\begin{abstract}
This article integrates insights from the latest research on the lean startup entrepreneurial method, born-global firms, and global startups. It contributes to the clarification of terminology referring to the global aspects of startups, summarizes insights from previous literature focusing on global startups, and further substantiates the articulation of the need for considering the lean global startup as a new type of firm. The main message is that the lessons learned from the emergence of lean startup entrepreneurship offer a basis for promoting a similar lean phase in technology-based global startup research and practice. The analysis should benefit both researchers and practitioners in technology entrepreneurship, international entrepreneurship, and global innovation management.
\end{abstract}

\section{Introduction}

This article examines some of the developments following the publication of my earlier article in this journal (Tanev, 2012), in which I summarized the characteristics of born-global firms in a context relevant to new technology startups. I defined a born-global firm as a new venture that acts to satisfy a global niche from day one by searching for and accessing resources that could help its global reach. The definition focuses on new ventures that are international or global by design and not by emergence.

Since the publication of my 2012 article, there have been two major developments that could be both related to the context of born-global technology startups. The first one was the spread of the lean startup movement (Ries, 2012) as a systematic articulation of a set of entrepreneurial practices inspired by the customer development process suggested earlier by Steve Blank (2007). Blank's approach was described in greater detail in the Startup Owner's Manual (Blank \& Dorf, 2012) as a step-by-step process for managing the search for a new business model, providing entrepreneurs with a practical path from idea to a scalable business model. It could be considered as an enhancement of Moore's (1991) technology adoption lifecycle approach, because it offers a more systematic way of dealing with the entrepreneurial challenges of "crossing the chasm" between the early adopters and the first viable market niche. Eisenmann, Ries, and Dillard (2012) defined a lean startup as a firm that follows a hypothesis-driven approach to the evaluation of an entrepreneurial opportunity and the development of a new product for a specific market niche. The lean startup approach has also attracted the attention of entrepreneurship researchers trying to position its key insights in the context of existing management and innovation theories (Frederiksen \& Brem, 2017; Stolze et al., 2014).

The second development is the further maturation of international entrepreneurship research. I could refer to several recent research papers (Alcácer et al., 2016; Cavusgil \& Knight, 2015; Coviello, 2015; Sarasvathy et al., 2014; Weerawardena et al., 2015; Yang \& Gabrielsson, 2017) as examples of key developments in the field. The paper by Coviello (2015) is particularly relevant for the context of new technology firms because it points out the relevance of born-global startup over born-global firm definitions and highlights the research relevance of the global intentions of startups at their inception instead of the characteristics of young firms that have undergone a successful internationalization. In an interview with the author as part of the current special issue, Coviello has also provided additional comments on the international entrepreneurship research maturation process and the possibility of considering the lean global startup as a new type of firm (Coviello \& Tanev, 2017). 


\section{Is There a Lean Future for Global Startups?}

\section{Stoyan Tanev}

The remainder of this article is structured as follows. First, I discuss some of the insights by Coviello (2015) that could be highly relevant for the context of new technology firms engaged in a global business path from their inception. Next, I identify the key lessons learned from research focusing on born-global startups. Finally, I offer additional arguments that could better highlight the benefits of considering lean global startups as a new type of organization/firm.

\section{Born-Global Firms or Global Startups?}

Coviello (2015) provides an explanation of the problem of using the term "born global" in the context of startups. One of Coviello's key points is that, in order "to study a 'new' international venture, it is important to investigate (for example) their decisions or actions when they are, in fact, still new." In other words, the identification of a firm as "born global" is not a post factum conclusion that is the result of looking at how successful a firm was in its internationalization efforts. In other words, there is a difference between firms that were truly born with the intent to serve multiple foreign markets and firms that simply happen to export early. The difference in firms' growth intentions at their very founding will definitely lead to the emergence of different internationalization paths resulting in qualitatively different growth modes. Studying the different growth modes without taking into account the difference in firms' intentions at their founding will not help the proper articulation of business design principles focusing on establishing new global startups. In addition, the call for a closer attention on firms' intentions at their founding should not neglect the fact that there could have been many activities contributing to the global orientation of the firm even before its formal founding. In many cases, the founders incorporate a new firm after having worked for years on their product and partnership development.

The second important point made by Coviello is that there is a much better term referring to the globalness of startups: "global startup". This term was introduced by Oviatt and McDougall (1994) almost at the same time as the term "born global" and has a different meaning. Indeed, using the two terms interchangeably is confusing. Oviatt and McDougall have specifically discussed the characteristics of global startups, including the drivers for the emergence of such firms as a "powerful economic engine" (Oviatt et al., 1995). In their view, a global startup is just one specific type of international new venture that seeks to derive competitive advantage by coordinating many organizational activities - not just export sales - across many countries from its very inception. The other three types of international new ventures are export/import startups, multinational traders, and geographically-focused startups. They differ from global startups by serving a smaller number of international markets (export/import startups and geographically-focused startups) or coordinating a smaller range of (mostly logistical) activities across different countries (multinational trader companies). The focus on two global startup criteria - many coordinated activities across countries and many international markets - is an important point because it emphasizes a key difference with the definition of born-global firms as "entrepreneurial startups that, from or near their founding, seek to derive a substantial proportion of their revenue from the sale of products in international markets" (Knight \& Cavusgil, 2004) or "young companies that derive a significant portion of their revenue from international sales" (Cavusgil \& Knight, 2015). The broader focus of the international new venture definition includes the possibility for the coordination of activities other than export, such as importing, offshore $R \& D$, joint ventures, or production subsidiaries (Coviello, 2015). The broader international new venture definition of global startups fits much better with today's context of new technology firms that could and usually benefit from upstream activities across national borders before, or in parallel to, reaching sales capacity.

An additional aspect of the above discussion is the need to account for the difference between "international" and "global". Coviello points out that "Oviatt and McDougall (1994) specifically chose to use the term 'international new venture' (encompassing four types of firms) because many of the firms they observed did not have a global focus. Rather, most competed primarily in their regional markets or in a relatively limited number of countries" (Coviello, 2015). This statement implies that the key criterion for qualifying a new firm as a global startup focuses on the quantitative measure corresponding to the multiplicity of the international markets served and not so much on the geographical and cultural distance between these multiple markets. Such implication opens two interesting questions.

The first question is whether the tangibility of this measure contradicts the intentional character of the earlystage activities of startups. On the one hand, following Coviello's advice, we should focus on the actual intentions of the startups to serve multiple foreign markets at their inception and, on the other hand, on the multiplicity of international markets served by the startups and their various activities coordinated across different 


\section{Is There a Lean Future for Global Startups?}

\section{Stoyan Tanev}

countries. The problem here is in the difference between intending to serve and actually serving, intending to coordinate, and actually coordinating. How many startups could actually serve multiple international markets and coordinate many activities across multiple countries at their very inception?

The second interesting question is whether the meaning of "global" should be restricted to refer to the multiplicity of international markets and coordinated activities across multiple countries without any additional requirements for the geographical, psychic, and cultural distance between these countries. Should the export of a Danish firm to Germany, or a Canadian firm to the Unites States, be considered as part of their global market reach? It is not by accident that Madsen and Servais (1997) define born globals as "firms that seek to derive significant advantages from the use of resources from or the sale of outputs to multiple countries/continents right from their legal birth." The use of continents as a potential global location on an equal basis with countries indicates the tendency to associate the meaning of "global" with locations at significant geographical, psychic, and cultural distances. Another expression of this tendency is the recent definition of born-global firms suggested by Andersson, Evers, and Griot (2013): "business organizations that have a global mindset from inception and aim to derive significant competitive advantages from the use of resources and the sale of outputs in multiple countries spanning the three economic trading blocs of NAFTA, EU and AsiaPacific." This definition refers to the initial intentions of the firms with respect to both resources and markets, and it emphasizes a multi-continent perspective on globalness that is inclusive of the context of startups.

At the end of the present section, one could reiterate the judgement by Lopez and colleagues (2009) that the born-global literature has been lacking a precise definition of what a born-global firm is, and some existing definitions are tautological. In this sense, the call for more terminological clarity and for a new more mature phase of international entrepreneurship research made by Coviello (see her interview in this special issue: Coviello \& Tanev, 2017) is timely and highly relevant. One specific point could be particularly emphasized: "using the terms INV [international new venture] and BG [born global] synonymously and/or interchangeably is inaccurate, as is any reference to firms as 'INVs/BGs'" (Coviello, 2015). Rather, it is important to recognize that, by definition, these organizational forms differ.
For example, a study of firms labeled as born global will examine firms that, very close to birth, actively export to global markets. If the study captures multiple and global value chain activities very close to birth, the term "global startup" from Oviatt and McDougall's (1994) typology of international new ventures is more appropriate" (Coviello, 2015). At the same time, the overall spirit of the definitions seems to predominantly reflect the context of younger small firms and not of actual startups. Actual startups deal with the challenges of maximizing the value of resources acquired ex ante from factor markets; younger small firms deal with the challenges of capturing value by competing on product markets (Schmidt \& Keil, 2013). This was one of the key reasons for proposing the integration of the lean startup and the born-global or global startup paradigms. The next section will summarize some of the insights about global startups such as articulated by Oviatt, McDougall, and Loper as early as 1995, and by others after them.

\section{The Emergence of the Global Startup Phenomenon}

In their paper, Oviatt and colleagues (1995) do not seem to overemphasize their initial definition. It is in a footnote that they mention that a global startup is a type of international new venture that coordinates many organizational activities across many countries. In the main text, they add that "such firms seem to have aggressive growth objectives in that they rapidly exploit technological advantages, acquire foreign technologies, and follow clients into foreign lands" (Oviatt et al., 1995). According to them, the emerging phenomenon of rapid internationalization has become a reality due to specific technological and competitive forces. In addition, the factors enabling early internationalization have affected the formation of new ventures and made the usual slowly staged internationalization efforts risky for many firms.

Oviatt and colleagues (1995) summarized the forces that drive the emergence of new global startups by suggesting that entrepreneurs, investors, and corporate executives exploring venturing options should consider the following six conditions when determining whether a new business should be a global or a domestic startup.

1. The best human resources are dispersed among various countries. Certain locations in the world offer access to unique workforce skills. Global startups could profit from actual presence in such locations by procuring the best resources at lower prices. 


\section{Is There a Lean Future for Global Startups?}

\section{Stoyan Tanev}

2. Foreign financing could be easier or more suitable. Startups having difficulties in raising financing could benefit from pursuing funding outside their own countries of origin. According to Oviatt and colleagues (1995) the international sourcing of funds may be one of the most important forces driving startups to internationalize because of the inherent benefits of overseas funding. "Foreign investors will want their venture to move rapidly into their own markets, and founders will certainly consider moving into a country from which they have received funding. In some cases, a prime motivation of foreign investors may be to get new technology into their own home market." (Oviatt et al., 1995).

3. The target customers require the new venture to be international. The increasingly global nature of demand in many markets is one of the main forces encouraging the formation of global startups.

4. Rapid worldwide communications allow for quick competitive responses. The pervasive availability of rapid communications and transportation capabilities worldwide has enabled almost instantaneous access to information about virtually any market. Entrepreneurs in foreign countries can learn quickly about potential business opportunities in any other country. In addition, there is a variety of unprotected market niches at different global locations. Many startups became global because quite often "the best domestic defense might be a superior international offense" (Oviatt et al., 1995).

5. Worldwide sales are required to support the venture. Many industries cannot afford the comfort of remaining regional or national. Worldwide sales might be needed to justify large $R \& D$ expenses and to effectively address the target market. A global startup enjoys more potential customers than a domestic venture selling the same product. Some startups could actually be forced to target foreign customers because of the insufficiency of revenue in their home countries. Oviatt and colleagues (1995) call such firms "reluctant global startups". They do not have a global strategy from the start but need to be large to be effective, and being international is a vehicle for doing that.

6. Domestic inertia will be crippling if internationalization is postponed. If a new venture starts out domestically, its policies and procedures are driven by the logic of the domestic market. A newly emerging international market opportunity will most likely lead to the need of disruptive operational changes that could be met with resistance by its employees. It may take great efforts and a long time to overcome such inertia. An initial international orientation facilitates the adoption of operational standards and product architectures that permit easy internationalization (Oviatt et al., 1995). In brief, a global startup benefits in the long run from being international at inception.

In addition to summarizing the key factors enabling early internationalization, Oviatt and colleagues (1995) have identified seven characteristics that are commonly associated with the survival and growth of global startups, including:

1. Existence of a global vision from inception. The founders must be able to compellingly communicate a global vision to everyone else associated with the venture.

2. Founders or top managers are internationally experienced. Understanding the logic of cross-border business conduct is absolutely necessary.

3. The entrepreneurs have strong international business networks. New ventures are resource poor and usually depend on a supportive network of business associates. "Having a network of international alliances to access vital resources rather than owning those resources outright is the increasingly preferred way of conducting international business." (Oviatt et al., 1995).

4. Exploitation of preemptive technology or marketing approach. Most successful global startups begin by selling a unique product or service in leading markets. The way for them to overcome the advantages of indigenous firms is to be first to market with a distinctively valuable product or service.

5. Possession or privileged access to a unique intangible asset. Marketing a distinctively valuable product is preemptive only if its distinctiveness is sustained through a competitive advantage. In most cases, the competitive advantage is some type of unique special knowledge that only the startup has. Global startups should recruit, train, and manage their human resources very effectively and use them to continuously innovate. 


\section{Is There a Lean Future for Global Startups?}

\section{Stoyan Tanev}

6. There is a close link between product or service extensions. Continuous innovation ensures that a firm's advantage is a moving target that is more difficult for competitors to hit. Yet, innovations subsequent to the founding of the startup must be incremental due to the venture's limited experience and resources. Successful global startups seem to follow their initial product or service with extensions that are closely linked to the unique assets from which they derived their original competitive advantage.

7. The organization is closely coordinated worldwide. All the above characteristics would require a strong top management team to coordinate $\mathrm{R} \& \mathrm{D}$, procurement, production, marketing, distribution, sales, and other activities in several worldwide locations that need to be closely coordinated. Such close coordination implies several things, including: i) a close interaction among top managers aligned with a strong commitment to the main goals of the new venture; ii) efficient communication of the global vision throughout the organization to ensure every employee's commitment to that vision; iii) top managers should enjoy and endure travel: international business requires face-to-face meetings to establish and nurture the network of international business associates; and iv) the technological communication infrastructure of a successful global startup must be more sophisticated than that of the usual domestic startup of equal size.

Meyer and Xia (2012) offer additional insights about global startups by focusing on the experience of British global entrepreneurs. They emphasize that the pursuit of global markets is only one way to exploit global opportunities. Many ambitious entrepreneurs, especially in high-tech ventures, push further and create business models that explore and exploit resources in multiple countries. The actuation of the opportunity behind these business models involves the need to identify, attract, transform, and apply resources in different countries, but it also requires a focus on the implementation of the business idea from day one. Meyer and Xia (2012) also provide examples of British high-tech startups that would not have existed if they did not develop business models by tapping into resources all around the world. According to them, there are three globalization trends that stand out in creating opportunities for global entrepreneurs: global value chain fine-slicing, global communities of practice, and global communications technologies.
The global value chain fine-slicing trend has emerged within the dominant practices of most multinational companies that tend to locate different tasks in different countries and selectively outsource some of these tasks. Examples of such tasks are manufacturing, backoffice services, collaborative research, and acquisition of innovations from independent technology firms through licensing or specific contractual arrangements. According to Meyer and Xia (2012), the emerging granularity of the localization of these tasks creates opportunities for entrepreneurs to tap into a value chain by developing a specialized component or service targeted at major players in an industry. The emergence of such opportunities requires a certain degree of modularity within the dominant product design and architecture that would allow the pursuit of a displacement innovation (Christensen et al., 2004).Displacement is a specific type of innovation that could take place at a point of modularity by targeting the mainstream market. A new globally-minded startup could specialize by focusing on one particular component of a product or service and positioning it competitively in a global value chain by taking part of the market from well-established multinational incumbents. Such startups cannot win unless their products can interface with the established product architecture at points of well-defined modularity. This becomes possible when the interactions across the interfaces between different product components or modules are well understood and predictable. Interestingly, displacements could also enable low-end disruption by new startups that emerge by assembling value chain components in new ways to offer new customer benefits (Christensen et al., 2004). A good example of a company that was able to do that is Dell - it took advantage of the modularity of personal computers and developed its low-end disruptive business model. The example demonstrates the opportunity of articulating global startup design principles by incorporating insights based on theories of disruption (Gans, 2016).

The global communities of practice trend has emerged within many fields of specialization where close communities have evolved between experts who, despite geographic distances, meet frequently, exchange ideas and best practices, and establish informal rules of conduct in the community. For example, academic and industry-based researchers participate in conferences worldwide where they exchange ideas on new technologies and establish actual global networks. Such conferences allow researchers to create personal 


\title{
Is There a Lean Future for Global Startups?
}

\author{
Stoyan Tanev
}

relationships with experts in multiple countries and global locations. Entrepreneurs can build on these ties when creating their own ventures, hiring, contracting, or simply accessing the best people, resources, tools, and assets across multiple geographically distant locations.

The emergence of the global communications technologies trend was already discussed above. The point is that many entrepreneurs have learned to employ existing communication technologies and many open source tools to combine occasional intensive face-toface meetings with more frequent, but shorter and practically costless virtual meetings. The interaction between members of a geographically dispersed team can easily become an everyday routine.

The reason for summarizing the three trends above was to emphasize that global entrepreneurs take advantage of these opportunities and design their business models by combining and exploiting talent and resources from all around the world. The vastly reduced set-up costs of communication technology systems enables new startups to make efficient interpersonal exchanges across large distances. The access to talent and resources worldwide allows startups to become global from the start by integrating complementary technological products developed by partners from multiple global locations, coordinating resources, working with distributors, and seeking additional support from investors. Most of the entrepreneurs who have succeeded in making a global move are mature individuals who have achieved professional success before either in business or in academia. According to Meyer and Xia (2012), the commonality between them is that they share a global mindset, deep industry experience, ability to build networks by connecting with the best in their industry and technological domain around the world, persistence in pursuing global business opportunities, and readiness to adopt a lean startup-like vision of the business given that it is not always that the first attempt that is the most successful. The latest research offers even stronger arguments that the reality of the present information age suggests the adoption of a new techno-economic paradigm for the emerging structures and processes in international business in general. The reality of the new paradigm includes the changing nature of the competitive advantages of places (a new understanding of locations), the competitive advantages and strategies of firms (a new understanding of ownership), and the governance structure of international business networks (a new understanding of internationalization) (Alcácer et al., 2016). The implications of the emergence of this paradigm should be explored further in the context of new technologybased global startups.

\section{The Emergence of the Lean Global Startup Paradigm}

This section will focus on some of the issues mentioned in the introduction, and it will offer additional argumentation that could substantiate the introduction of the lean global startup as a new type of firm. It will therefore indirectly address Coviello's pessimism: "At any rate, I don't consider a lean global startup to be a new form of organization or growth mode. Lean is a way of operating. In the same way that we study organization structure, orientation etc., we should study the influence of lean (or effectual logic) as young firms internationalize" (Coviello \& Tanev, 2017). It would be good to start with a reminder of the lean startup definitions as suggested by its "Godfathers": Steve Blank (2013) and Eric Ries (2011). The definitions of the lean startup emphasize several points:

- A lean startup is not a smaller version of a large company. Whereas well established companies focus on executing a business model, a startup struggles to articulate and establish one. In this sense, "a lean startup is a temporary organization designed to search for a repeatable and scalable business model" (Blank, 2013).

- A lean startup is "a human institution designed to create new products and services under conditions of extreme uncertainty" (Ries, 2012).

- Blank and Ries pioneered three key concepts to characterize the essence of lean startups: customer development, minimum viable product (MVP), and pivot. The MVP is a product consisting of a minimum set of features that is used, first, as a tactic to reduce wasted engineering hours and, second, as a way of getting the product in the hands of early and visionary customers as soon as possible. Pivot is a term used to describe a major change in direction of a startup while staying grounded in learning.

- A lean startup, as a temporary organization/institution, deals with the challenges and uncertainties of transforming the ex-ante value of resources acquired in factor markets into ex-post product market success of a newly created company. This transformation is associated with a business transition from a temporary startup mode of operation of a customer development 


\section{Is There a Lean Future for Global Startups?}

\section{Stoyan Tanev}

team searching for a business model, to a sustaining operational mode of a newly established company based on functional departments focusing on the execution of the business model (Blank, 2013).

- In parallel to the articulation of a viable business model, a lean startup is striving to build the minimum viable ecosystem (MVE) of partners that would enable the new company to demonstrate its potential to create value on the product market. The concept of MVE was introduced by Adner (2012) as one of the principles for the construction of a successful business ecosystem. The MVP and MVE concepts fit very well together. The link between MVP and MVE could be expressed as follows: establishing a viable business means using an MVP as part of a customer development approach to transforming a lean startup into a new company with a well-configured MVE. Such an understanding of new business creation resembles the definition of creation suggested by Deleuze (1998) - the act of making configurations.

The reason to provide a more detailed definition of the lean startup was to emphasize several points, as follows. First, the lean startup is a special type of startup; it is not just the early or immature stage of any startup. There are startups that are not lean startups. If we focus on the technology business area, we could say that the other type - regular or non-lean startups - usually focuses on intensive R\&D and product development until they come up with a product that is then in need of a market (i.e., technology and product development dominate over marketing). Such were most of the startups in the 1990s. Such are many of today's startups that do not really reach a viable business stage in the form of a well-established new company. The reason for Blank and Ries to introduce and insist on promoting the lean startup concept was exactly to differentiate the (lean) startup described above from the regular ones. According to their lean philosophy, "lean" is about reducing waste, and the greatest waste for a startup is to develop a product that nobody wants.

There is a danger of considering a lean startup just as an initial phase of a new startup that is preliminary to its future viable business stage. One can, of course, do that at the cost of missing the point and never reaching a viable business stage. The reason for the existence of such danger is that everything in the lean startup and in the viable business stage of the future new company is different - the type of product that is being developed, the type of customers being targeted, the type of em- ployees that need to be hired, and the type of business goals being set. This fact was realized as early as the 1990s through the promotion of the Crossing the Chasm approach articulated by Geoffrey Moore (1991). There is however a key difference in the messages of the lean startup and crossing-the-chasm approaches. The main focus of the crossing-the-chasm approach was to emphasize that: i) the early customers (i.e., enthusiasts, innovators, and early adopters) are not a startup's ultimate customer target market segment: the late adopters; ii) the technological solution that impresses the early adopters is not the whole product that is going to impress the late adopters - the startup should focus on interacting with customers to help the development of the whole product; iii) the initial marketing approach to early adopters is not the way to deal with later adopters.

The lean startup approach could be seen as a valuable development of Moore's crossing-the-chasm approach. The lean startup "new development" consists of shifting the above messages into another key: i) the lean startup is not the company that the entrepreneur is trying to build; ii) the product of the lean startup is not its product but the business model; and iii) the focus of product development should be on using customer feedback to evolve the MVP into an awesome product that is going to impress the first customer target niche (i.e., product development is based on customer development). In this sense, the lean startup concept emphasizes two key differences: lean startups versus other (non-lean) startups and lean startups versus the companies that are going to be built on them. The claim that a lean startup is a temporary organization amplifies the emphasis of the second difference. According to Blank (2007), "The idea of not having a functional organization until the organization has found a proven business model is one of the hardest things for new startups to grasp" (Blank \& Dorf, 2012). The current knowledge in global startup research and practice could greatly benefit from a similar enhancement based on the lean startup concept.

Second, it is clear that global startups have been studied before as a special type of international new venture and should not be considered as something new in both business practice and research. The purpose of the section of this article dedicated to global startups was to illustrate this fact. The global startup literature, however, does not seem to address the ongoing adoption, popularity, and relevance of the lean startup approach. The lean startup literature does not speak about the opportunities of a global start either. The lean 


\title{
Is There a Lean Future for Global Startups?
}

\author{
Stoyan Tanev
}

global startup concept was introduced with the intention of linking the aspects of lean and global (Lemminger et al. 2014; Tanev et al., 2015; Rasmussen \& Tanev, 2015). Almost at the same time, Steve Blank (2014) followed-up with a valuable insight: Startups have to be born global or die local because most countries do not have sufficient population to support a potential scale up with their local market (i.e., growth-oriented startups ultimately need to become global players from day one). In the definition of lean global startup, "lean" refers to global and employs a lean startup logic that is similar to the one described above. A lean global startup adopts the lean approach as part of its global move and not simply as part of its product and customer development strategies focusing on addressing a first local market niche. In a typical lean global startup, the target market niche would be at a global location and all local marketing efforts would be in parallel to the global one or for the sake of experimentation and learning. It is clear, however, that there could be global startups that are not lean startups. In this sense, it would be highly beneficial to consider the lean global startup as a unique firm type.

Third, the global startup definition suggested by Oviatt and McDougall's (1994) and Oviatt, McDougall, and Loper (1995) does not appear to be good enough to address the context of actual technology startups that have adopted a global marketing or global resourcing strategy from their inception. It misses some of the key points of the lean global startup context such as the multi-continent aspects of globalness and the evolutionary nature of a startup's transition to a newly established company. It appears to be too much attribute-based and not so much circumstance-based, to use the Christensen's (2006) terminology. More importantly, it does not seem to have taken into account the difference between the ex ante resource focus of early-stage startups and the ex post product market focus of established young companies. According to Doz and Wilson (2012), this is a typical problem for the managers of global organizations - judging the value or success of a global location by using ex post performance measurements of value. At the same time, the focus on the lean global startup context is a direct expression of Coviello's concern that international new ventures or global startups should be studied at their very early stages, when their initial intentions are most clearly articulated. In this sense, the introduction of the lean global startup concept appears to be quite useful in emphasizing the lean aspects of reaching a global presence. It is inclusive for both "finger-push" firms, with the potential to serve global markets, and for other startups that have committed to a more evolutionary lean global path from their start. Previous research offered examples of these two types of global startup scenarios and labelled them lean and global startups and lean-toglobal startups (Borseman et al., 2016; Rasmussen \& Tanev, 2015; Tanev et al., 2015). However, the meaning of "global" in the lean global startup definition has to be refined with respect to the global startup definition provided by Oviatt and McDougall (1994) by reducing the requirement for the quantitative intensity of the global resource coordination or market presence at the time of inception of a startup. For example, the simultaneous operation of a startup at two globally distant locations (for example, in two different continents) should be considered to be global enough for the sake of born global startup research. Establishing a new business in a foreign country enables the actualization of special innovative capabilities (Jones \& Coviello, 2005; Weerawardena et al., 2015; Zijdemans \& Tanev, 2014;). Once demonstrated in one specific country, these capabilities could be more easily replicated in other countries. A softer requirement for the quantitative intensity of the global upstream and downstream engagement of startups will allow the development of analytical and practical frameworks that would help globally-driven startups to pursue their global business path more systematically in the same way the lean startup approach does.

\section{Conclusion}

This article has two main contributions. The first one is taking into account some of the key insights from most recent research on born-global firms and, more specifically, the need for clarification and refinement of existing definitions by focusing on startups that have engaged into a global path from their very inception (Coveillo, 2015). On the one hand, it adopts the idea that existing born-global startup definitions provide a better fit to the startup context and summarizes some of the key lessons learned from born-global startup research (Meyer \& Xia, 2012; Oviatt et al., 1995). On the other hand, it offers a critical reflection on these insights and suggests that existing definitions remain grounded in the context of younger firms and not so much on actual startups. The second contribution is the summary of the characteristics of lean startups in a way that could help further substantiate the claim about the benefits of considering lean global startups as a new type of organization/firm. The analysis suggests that the lessons learned from the emergence of lean 


\section{Is There a Lean Future for Global Startups?}

\section{Stoyan Tanev}

startup entrepreneurship offer a basis for promoting a similar lean phase in technology-based global startup research and practice. Last but not least, international entrepreneurship research could greatly benefit from adopting a global instantiation of the lean startup paradigm in addressing the actual context of new technology firms dedicated to operating in a global context from their very inception.

\section{About the Author}

Stoyan Tanev is an Associate Professor in the Department of Technology and Innovation, Faculty of Engineering, Southern Denmark University (SDU) in Odense. Dr. Tanev is leading the Technology Entrepreneurship stream of the Master Program of Product Development and Innovation at SDU. He is also an Adjunct Research Professor in the Sprott School of Business at Carleton University in Ottawa, Canada, where he is associated with the Technology Innovation Management Program. He has a MSc and a PhD in Physics jointly from the University Pierre and Marie Curie, Paris, France, and the University of Sofia, Bulgaria, a $\mathrm{PhD}$ in Theology from the University of Sofia, Bulgaria, an MEng in Technology Innovation Management from Carleton University, Canada, and an MA from the University of Sherbrooke, Canada. He has multidisciplinary research interests with a focus on the fields of global technology entrepreneurship, technology innovation management, business model design, and value co-creation. Dr. Tanev is Senior IEEE member, as well as member of the editorial boards of the Technology Innovation Management Review, the International Journal of Actor-Network Theory, and Technological Innovation.

\section{References}

Adner, R. 2012. The Wide Lens. What Successful Innovators See that Others Miss. New York: Portfolio/Penguin.

Alcácer, J., Cantwell, J., \& Piscitello, L. 2016. Internationalization in the Information Age: A New Era for Places, Firms, and International Business Networks? Journal of International Business Studies, 47(5): 499-512.

http://dx.doi.org/10.1057/jibs.2016.22

Andersson, S., Evers, N., \& Griot, C. 2013. Local and International Networks in Small Firm Internationalization: Cases from the Rhône-Alpes Medical Technology Regional Cluster. Entrepreneurship \& Regional Development, 25(9-10): 867-888. http://dx.doi.org/10.1080/08985626.2013.847975
Blank, S. 2007. The Four Steps to the Epiphany - Successful Strategies for Products that Win. Raleigh, NC: Lulu Enterprises.

Blank, S. 2013. Why the Lean Start-Up Changes Everything. Harvard Business Review, 91(5): 63-72.

Blank, S. 2014. Born Global or Die Local - Building a Regional Startup Playbook. SteveBlank.com, October 31, 2014. Accessed May 1, 2017: http://steveblank.com/2014/10/31/born-global-or-die-localbuilding-a-regional-startup-playbook/

Blank, S., \& Dorf, B. 2012. The Startup Owner's Manual: The Step-byStep Guide for Building a Great Company. Pescadero, CA: K\&S Ranch Incorporated.

Borseman, M., Tanev, S., \& Weiss, M. 2016. Lost in the Canvases: Managing Uncertainty in Lean Global Startups. In Proceedings of ISPIM Innovation Forum: Charting the Future of Innovation Management, March 13-16, 2016, Boston, USA.

Cavusgil, S., \& Knight, G. 2015. The Born Global Firm: An Entrepreneurial and Capabilities Perspective on Early and Rapid Internationalization. Journal of International Business Studies, 46, 3-16.

http://dx.doi.org/10.1057/jibs.2014.62

Christensen, C., Roth, E., \& Anthony, S. 2004. Seeing What's Next: Using the Theories of Innovation to Predict Industry Change. Boston, MA: Harvard Business Review Press.

Christensen, C. 2006. The Ongoing Process of Building a Theory of Disruption. Journal of Product Innovation Management, 23(1): 39-55.

http://dx.doi.org/10.1111/j.1540-5885.2005.00180.x

Coviello, N. 2015. Re-Thinking Research on Born Globals. Journal of International Business Studies, 46(1): 17-26. http://dx.doi.org/10.1057/jibs.2014.59

Coviello, N., \& Tanev, S. 2017. Initiating a New Research Phase in the Field of International Entrepreneurship: An Interview with Professor Nicole Coviello. Technology Innovation Management Review, 7(5): 52-56.

http://timreview.ca/article/1077

Deleuze, G. 1998. Qu'est-ce que l'acte de création? Trafic, 27: 133-142.

Doz, Y., \& Wilson, K. 2012. Managing Global Innovation: Frameworks for Integrating Capabilities Around the World. Boston, MA: Harvard Business Review Press.

Eisenmann, T., Ries, E., \& Dillard, S. 2011. Hypothesis-Driven Entrepreneurship: The Lean Startup. Harvard Business School Entrepreneurial Management Case No. 812-095.

https://papers.ssrn.com/sol3/papers.cfm?abstract_id=2037237

Frederiksen, D., \& Brem, A. 2017. How do Entrepreneurs Think They Create Value? A Scientific Reflection of Eric Ries' Lean Startup Approach. International Entrepreneurship and Management Journal, 13(1): 169-189.

http://dx.doi.org/10.1007/s11365-016-0411-x

Gans, J. 2016. The Disruption Dilemma. Cambridge, MA: The MIT Press.

Jones, M. V., \& Coviello, N. E. 2005. Internationalisation: Conceptualising an Entrepreneurial Process of Behaviour in Time. Journal of International Business Studies, 36(3): 284-303. http://dx.doi.org/10.1057/palgrave.jibs.8400138 


\section{Is There a Lean Future for Global Startups?}

\section{Stoyan Tanev}

Jones, M., Coviello, N., \& Tang, Y. 2011. International Entrepreneurship Research (1989-2009): A Domain Ontology and Thematic Analysis. Journal of Business Venturing, 26(6): 632-659. http://dx.doi.org/10.1016/j.jbusvent.2011.04.001

Knight, G., \& Cavusgil, S. 2004. Innovation, Organizational Capabilities, and the Born-Global Firm. Journal of International Business Studies, 35: 124-141. http://dx.doi.org/10.1057/palgrave.jibs.8400071

Lemminger, R., Svendsen, L., Zijdemans, E., Rasmussen, E., \& Tanev, S. 2014. Lean and Global Technology Start-ups: Linking the Two Research Streams. In Proceedings of the ISPIM Americas Innovation Forum, October 4-8, 2014, Montreal, Canada.

Lopez, L., Kundu, S., \& Ciravegna, L. 2009. Born Global or Born Regional? Evidence from an Exploratory Study in the Costa Rican Software Industry. Journal of International Business Studies, 40(7): 1228-1238.

http://dx.doi.org/10.1057/jibs.2008.69

Madsen, T. K, \& Servais, P. 1997. The Internationalization of Born Globals: An Evolutionary Process? International Business Review, 6(6): 561-583.

https://doi.org/10.1016/S0969-5931(97)00032-2

Meyer, K., \& Xia, H. 2012. British Entrepreneurs, Global Visions. Business Strategy Review, 23(2): 52-57. http://dx.doi.org/10.1111/j.1467-8616.2012.00846.x

Moore, G. A. 1991. Crossing the Chasm: Marketing and Selling HighTech Products to Mainstream Customers. New York: Harper Business.

Oviatt, B. M., \& McDougall, P. P. 1994. Toward a Theory of International New Ventures. Journal of International Business Studies, 25(1): 45-64. http://dx.doi.org/10.1057/palgrave.jibs.8490193

Oviatt, B. M., McDougall, P. P., \& Loper, M. 1995. Global Start-Ups: Entrepreneurs on a Worldwide Stage. The Academy of Management Executive, 9(2): 30-44. http://www.jstor.org/stable/4165256

Rasmussen, E. S., \& Tanev, S. 2015. The Emergence of the Lean Global Startup as a New Type of Firm. Technology Innovation Management Review, 5(11): 12-19. http://timreview.ca/article/941

Ries, E. 2011. The Lean Startup: How Today's Entrepreneurs Use Continuous Innovation to Create Radically Successful Businesses. New York: Crown Business.
Sarasvathy, S., Kumar, K., York, J. G., \& Bhagavatula, S. 2014. An Effectual Approach to International Entrepreneurship: Overlaps, Challenges, and Provocative Possibilities. Entrepreneurship Theory and Practice, 38(1): 71-93.

http://dx.doi.org/10.1111/etap.12088

Schmidt, J., \& Keil, T. 2013. What Makes a Resource Valuable? Identifying the Drivers of Firm-idiosyncratic Resource Value. Academy of Management Review, 38(2): 206-228. http://dx.doi.org/10.5465/amr.2010.0404

Stolze, A., Arnsfeld, T., Kelly, L., \& Lüdtke, C. 2014. The Lean Startup Status Quo: Deconstructing the Lean Start-Up Movement to Assess its Validity as a Strategic Planning Tool for Entrepreneurs. Working Paper No. 3. Faculty of Business Management and Social Sciences. Osnabrück, Germany: Osnabrück University of Applied Sciences.

Tanev, S. 2012. Global from the Start: The Characteristics of BornGlobal Firms in the Technology Sector. Technology Innovation Management Review, 2(3): 5-8.

http://timreview.ca/article/532

Tanev, S., Rasmussen, E. S., Zijdemans, E., Lemminger, R., \& Limkilde, L. 2015. Lean and Global Technology Start-Ups: Linking the Two Research Streams. International Journal of Innovation Management, 19(3): 1540008. http://dx.doi.org/10.1142/S1363919615400083

Weerawardena, J., Mort, G. S., Salunke, S., Knight, G., \& Liesch, P. W. 2015. The Role of the Market Sub-System and the Socio-Technical Sub-System in Innovation and Firm Performance: A Dynamic Capabilities Approach. Journal of the Academy of Marketing Science, 43(2): 221-239.

http://dx.doi.org/10.1007/s11747-014-0382-9

Yang, M., \& Gabrielsson, P. 2017. Entrepreneurial Marketing of International High-Tech Business-to-Business New Ventures: A Decision-Making Process Perspective. Industrial Marketing Management. http://dx.doi.org/10.1016/j.indmarman.2017.01.007

Zijdemans, E., \& Tanev, S. 2014. Conceptualizing Innovation in BornGlobal Firms. Technology Innovation Management Review, 4(9): $5-10$ http://timreview.ca/article/826 